\title{
Reuse Resource of Food Processing Sludge-Derived Fuel Incinerated Ash
}

\section{Ing-Jia Chiou ${ }^{1 *}$, Jun-Pin Su${ }^{2}$, Ching-Ho $\mathrm{Chen}^{3}$ and I-Tsung $\mathbf{W u}^{1}$}

${ }^{1}$ Department of Environmental Technology and Management, Taoyuan Innovation Institute of Technology, No. 414, Sec. 3, Jhongshan E. Rd., Jhongli, Taoyuan 320, Taiwan ${ }^{2}$ Department of Natural Resource, Chinese Culture University, 55, Hwa-Kang Road, Yang-Ming-Shan, Taipei , 11114, Taiwan

${ }^{3}$ Department of Social and Regional Development, National Taipei University of Education, No. 134, Sec. 2, Heping E. Rd., Taipei City 106, Taiwan

\begin{abstract}
The heat value of food processing sludge is similar to that of bituminous coal, thus is suitable as biofuel; however, the problem of incinerated ash disposal after combustion should be address. This study evaluated the applicability of food processing sludge-derived fuel incinerated ash (FA) to pozzolanic material and soil improvement, and proposed reuse strategies. When applied to pozzolanic material, the addition of FA reduced the hydration heat of fresh incinerated ash cement paste (FACP) significantly (85.96 91.23\%), and prolonged the initial setting times $(87.88 \sim 134.85 \%)$ and final setting times (87.88 134.85\%) of FACP significantly. When the FA addition was $10 \%$ and $20 \%$ respectively, the pozzolanic strength activity index (SAI) was greater than $75 \%$ until the hardened FACP was cured for 28 days and 90 days respectively. When applied in soil improvement, the final seed germination of Chinese cabbage and water spinach in the original soil (ash content $0 \%$ ) and improved soil (ash content $20 \%$ ) was $98 \%$ and $90 \%$ respectively. There was no significant effect on the growth rate of Chinese cabbage and water spinach.
\end{abstract}

Keywords: Food processing sludge-derived fuel incinerated ash (FA); Pozzolanic material; Soil improvement; Germination

\section{Introduction}

According to the statistics of Industrial Development Bureau of ROC, about 12 million MT industrial waste could be reused directly in 2012 , about $88 \%$ was used in construction engineering. The fresh concrete uses pozzolanic materials of fly ash, furnace slag and silica fume. The cement content can be reduced, and the durability and working performance can be improved. The pozzolanic material has become an important material for enhancing the concrete performance and quality. In addition, about 90,000 MT industrial waste was reused for soil improvement in 2012, meaning the industrial waste can be applied to soil improvement. According to Taiwan Ready-Mixed Concrete Industry Association, the consumption of ready-mixed concrete has been stable in Taiwan in recent years, namely 40 million $\mathrm{m}^{3} /$ year in 2012. If each cubic meter concrete is mixed with $10 \%$ mineral admixtures (e.g. coal ash and slag), the concrete industry has a large demand for mineral admixtures.

The concrete can use pozzolanic material to partially replace cement or aggregate, not only to improve the concrete performance, but also to reuse the waste. A great variety of pozzolanic materials is used extensively, such as blast furnace slag [1], silicomanganese slag [2], pulp sludge incinerated ash [3], sugarcane incinerated ash [4], palm oil fuel incinerated ash , rice husk ash $[5,6]$, waste glass, ceramics, metakaolin, swelling clay [7-9], cattle manure incinerated ash, coal ash [10], semiconductor industry sludge [11], and TFT-LCD waste glass [12]. Some studies have used industrial wastes, such as soda-lime glass [13], industrial sludge, ocean sludge, fly ash [14-16], waste glass, recycled concrete aggregate and slag, to make artificial aggregate and lightweight aggregate $[17,18]$. The incinerated ash of the derived fuel made from the mixture of pulp sludge and textile sludge is suitable as the filler of controlled low-strength materials (CLSM) [19]. To sum up, the incinerated ash of different industries mostly has pozzolanic effect, applicable to cement, aggregate and concrete materials.

As the heat value of food processing sludge is similar to that of bituminous coal, it is suitable as biofuel. After the food processing sludge-derived fuel with high heat value is combusted, there is problem of FA disposal. Therefore, this study uses the properties of FA, rheological properties and mechanical properties of FACP and the seed germination to evaluate the feasibility of FA to pozzolanic material and soil improvement, and proposes reuse strategies. The purpose to handle the disposal of FA and achieve "zero waste".

\section{Methodology}

\section{Experimental materials}

This study used the dewatered sludge from a food processing plant that produces dairy products and beverage in Taoyuan City. The food processing sludge-derived fuel was produced by preprocessing and extrusion at normal temperature. The mixture of derived fuel was mixed with $10 \%$ lime $\left(\mathrm{Ca}(\mathrm{OH})_{2}\right)$ in the extrusion process, so as to reduce the emission of contaminants (e.g. SOx, NOx). As the sludge-derived fuel was used for boilers, where the flame temperature can reach over $900^{\circ} \mathrm{C}$ [20], the combustion was maintained at this temperature for $2 \mathrm{~h}$. When the FA was cooled, crushed and sieved (<\#100 sieve), the fineness was $250 \mathrm{~m}^{2} / \mathrm{kg}$ (Blaine) (Table 1). The cement met the specification of CNS 61 "Portland cement" with a fineness of $300 \mathrm{~m}^{2} / \mathrm{kg}$ (Blaine) (Table 1).

The soil samples were collected from a farmland in Taoyuan City without heavy metal pollution. The soil was crushed and sieved to prepare the original soil. The fineness modulus of the sieved original soil was 3.0. The original soil was mixed with $20 \%$ incinerated ash thoroughly to prepare the improved soil.

\section{Methods}

*Corresponding author: Ing-Jia Chiou, Department of Environmental Technology and Management, Taoyuan Innovation Institute of Technology, No. 414, Sec. 3 Jhongshan E. Rd., Jhongli, Taoyuan 320, Taiwan, Tel: 886-3-4361071; E-mail: cij@ tiit.edu.tw

Received November 22, 2015; Accepted December 10, 2015; Published December 17,2015

Citation: Chiou IJ, Su JP, Chen CH, Wu IT (2015) Reuse Resource of Food Processing Sludge-Derived Fuel Incinerated Ash. Int J Waste Resour 5: 187. doi: 10.4172/2252-5211.1000187

Copyright: $\odot 2015$ Chiou IJ, et al. This is an open-access article distributed unde the terms of the Creative Commons Attribution License, which permits unrestricted use, distribution, and reproduction in any medium, provided the original author and source are credited. 
There were four weight ratios of cement (PC) in this study, $100 \%$, $90 \%, 80 \%$ and $70 \%$. The weight ratio of FA addition was $0 \%, 10 \%, 20 \%$ and $30 \%$ respectively. They were mixed to make FACP (FACP numbers are PC100FA0, PC90FA10, PC80FA20 and PC70FA30). The water to cement ratio was determined at standard flow (i.e. $110 \pm 5 \%$ ) to make 1 cubic inch FACP. The specimen was cured in $25^{\circ} \mathrm{C}$ saturated limewater for 3 to 120 days. The impact of FA addition level on the pozzolanic effect of FACP was discussed.

This study used original soil (with $0 \%$ FA) and improved soil (with $20 \%$ FA), as well as Chinese cabbage and water spinach seeds. The soil was placed in well drained plastic containers $(60 \mathrm{~cm} \times 20 \mathrm{~cm})$, tested according to the standard germination rate specified by International Seed Testing Association (ISTA). Experiments were conducted in replicates. Each plastic container was divided into 5 blocks, and each block was planted with 20 seeds, meaning each container was planted with 100 seeds (Figure 1). The data were recorded on a daily basis for 30 days to observe the seed germination and growth rate of Chinese cabbage and water spinach.

The chemical composition of FA (Table 1) was mainly $\mathrm{Fe}_{2} \mathrm{O}_{3}, \mathrm{CaO}$ and $\mathrm{P}_{2} \mathrm{O}_{5}$, accounting for $27.35 \%, 22.70 \%$ and $18.63 \%$ respectively, and then $\mathrm{SiO}_{2}, \mathrm{Al}_{2} \mathrm{O}_{3}, \mathrm{SO}_{3}, \mathrm{~K}_{2} \mathrm{O}, \mathrm{MgO}$ and $\mathrm{Na}_{2} \mathrm{O}$, accounting for $11.07 \%$, $9.03 \%, 6.91 \%, 1.77 \%, 1.73 \%$ and $0.82 \%$ respectively. The $\mathrm{CaO}$ content in FA was $22.7 \%$, resulted from the addition of $10 \%$ lime $\left(\mathrm{Ca}(\mathrm{OH})_{2}\right)$ to the food processing sludge-derived fuel. The $\mathrm{CaO}$ in $\mathrm{FA}$ was much lower than Portland cement, meaning the activity of FA was lower than cement. According to the SEM image, the FA was irregular particles (Figure 2). The water soluble chloride ion $\left(\mathrm{Cl}^{-}\right)$content in $\mathrm{FA}$ was $0.071 \%$, apparently higher than CNS 3090 specifications. The $\mathrm{Cl}^{-}$content in the reinforced concrete was required to be lower than $0.024 \%$, meaning the FA is inapplicable to reinforced concrete. According to the XRD crystalline phase spectrum, the $\mathrm{CaSO}_{3}$ and $\mathrm{CaO}$ of FA had high peak strength, followed by $\mathrm{AlPO}_{4}$ and $\mathrm{Ca}(\mathrm{OH})_{2}$. The incinerated ash $\mathrm{pH}$ was 10.21 , and was alkaline.

\section{Results and Discussion}

\section{Application on cement materials}

Rheological properties of fresh cement pastes: The rheological properties of fresh FACP were evaluated by hydration heat, setting time and consistency. The flow value of fresh FACP was controlled within

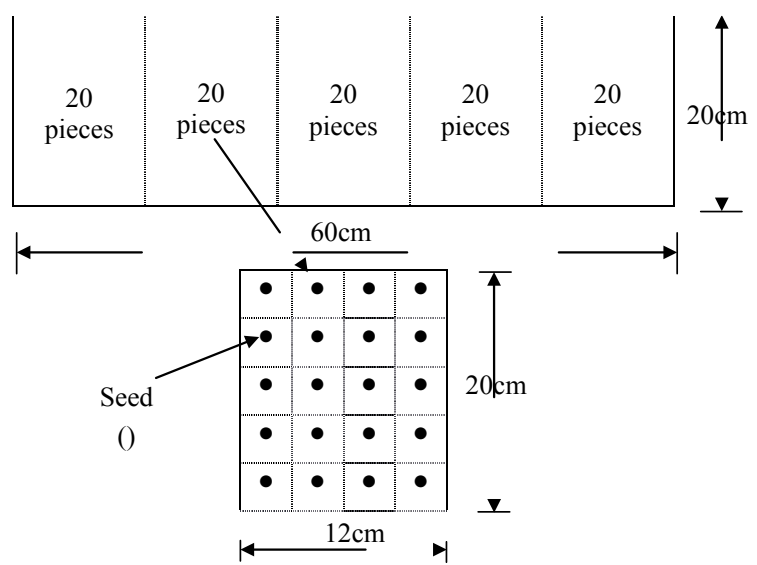

Figure 1: Schematic diagram of germination rate test. the standard flow range (100-115\%), so as to obtain the optimal mixing water consumption. At the standard flow (103 104\%), the watercement ratio corresponding to mix proportions PC100FA0, PC90FA10, PC80FA20 and PC70FA30 was $0.36,0.38,0.40$ and 0.44 respectively (Table 2). In other words, for each addition of $10 \% \mathrm{FA}$, the mixing water for fresh FACP was increased by $6.5 \%$, meaning the FA has high water absorption.

The initial setting time of mix proportions PC100FA0, PC90FA10, PC80FA20 and PC70FA30 was $293 \mathrm{~min}, 471 \mathrm{~min}, 580 \mathrm{~min}$ and 705 min respectively, which was longer than the initial setting time of mix proportion PC100FA0 by $60.75 \%, 97.95 \%$ and $140.61 \%$ respectively. The final setting time was $330 \mathrm{~min}, 620 \mathrm{~min}, 661 \mathrm{~min}$ and $775 \mathrm{~min}$ respectively, which was longer than the final setting time of mix proportion PC100FA0 by $87.88 \%, 100.30 \%$ and $134.85 \%$ respectively (Table 2). For each addition of $10 \%$ incinerated ash, the initial setting time and final setting time of fresh FACP were prolonged by $49.89 \%$ and $53.84 \%$ respectively. The hydration heat of mix proportions PC100FA0, PC90FA10, PC80FA20 and PC70FA 30 was increased by $5.7^{\circ} \mathrm{C}, 0.8^{\circ} \mathrm{C}$, $0.6^{\circ} \mathrm{C}$ and $0.5^{\circ} \mathrm{C}$ respectively, which was lower than the hydration heat of mix proportion PC100FA0 by $85.96 \%, 89.47 \%$ and $91.23 \%$ respectively (Figure 3). The addition of FA reduced the hydration heat of FACP significantly (85.96 91.23\%), and prolonged the initial setting time (87.88 134.85\%) and final setting time (87.88 134.85\%) of FACP significantly. This phenomenon was due to the fact that $\mathrm{CaO}$ and fineness of FA are apparently lower than cement.

Properties of hardened cement pastes: The FA addition level was $0 \%, 10 \%, 20 \%$ and $30 \%$ respectively in this study. The SAI of the hardened FACP should be $75 \%$ of control group at the curing age of 28 days, so as to evaluate whether it can be used as pozzolanic material. The compressive strength on Day 3 of mix proportions PC100FA0, PC90FA10, PC80FA20 and PC70FA30 was $344 \mathrm{kgf} / \mathrm{cm}^{2}, 246 \mathrm{kgf} / \mathrm{cm}^{2}$, $206 \mathrm{kgf} / \mathrm{cm}^{2}$ and $148 \mathrm{kgf} / \mathrm{cm}^{2}$ respectively. The compressive strength on Day 28 was $514 \mathrm{kgf} / \mathrm{cm}^{2}, 406 \mathrm{kgf} / \mathrm{cm}^{2}, 349 \mathrm{kgf} / \mathrm{cm}^{2}$ and $289 \mathrm{kgf} / \mathrm{cm}^{2}$ respectively. The compressive strength on Day 120 was $708 \mathrm{kgf} / \mathrm{cm}^{2}, 618$ $\mathrm{kgf} / \mathrm{cm}^{2}, 547 \mathrm{kgf} / \mathrm{cm}^{2}$ and $450 \mathrm{kgf} / \mathrm{cm}^{2}$ respectively. The compressive strength on Day 3 of the four hardened FACPs was $93.22 \%, 77.85 \%$, $75.86 \%$ and $66.07 \%$ of compressive strength on Day 28 respectively. The mix proportions PC90FA 10 and PC80FA20 should be cured for 28 days and 90 days to meet the requirement of $\mathrm{SAI}>75 \%$. The mix proportion PC70FA30 did not meet the requirement of SAI $>75 \%$ at the curing age of 120 days (Figure 4). This phenomenon was resulted from the low hydration heat and low $\mathrm{CaO}$ content of FA.

The main crystalline phase species of FACP were $\mathrm{Ca}(\mathrm{OH})_{2}, \mathrm{CaCO}_{3}$ and $\mathrm{SiO}_{2}$. The peak strength of $\mathrm{Ca}(\mathrm{OH})_{2}$, was apparent (Figure 5), namely, the peak strength of $\mathrm{Ca}(\mathrm{OH})_{2}$ in the cement paste decreased slightly as the addition level of incinerated ash increases. It was observed that the peak strength of hardened FACP was reduced slightly as the pozzolanic reaction process consumes $\mathrm{Ca}(\mathrm{OH})_{2}$.

According to the SEM image of hardened cement paste, at the curing age of 7 days, the hydration product of mix proportion PC100FA0 increased gradually, in plate-like structure. The mix proportions PC90FA10, PC80FA20 and PC70FA30 had more particles and pores, especially the mix proportion PC70FA30. At the curing age of 60 days, the mix proportion PC100FA0 had obvious hydration product. The hydration products of mix proportions PC100FA0, PC90FA10 and PC80FA20 increased gradually. The mix proportion PC70FA30 had a little hydration product, mostly particles and pores. At the curing age of 120 days, the mix proportions PC100FA0, PC90FA10, PC80FA20 and PC70FA30 had apparent hydration products (Figure 6). 
Citation: Chiou IJ, Su JP, Chen CH, Wu IT (2015) Reuse Resource of Food Processing Sludge-Derived Fuel Incinerated Ash. Int J Waste Resour 5: 187. doi: 10.4172/22525211.1000187

Page 3 of 5

\begin{tabular}{|l|l|l|l|l|l|l|l|l|l|l|l|l|}
\hline Oxides (wt.\%) & $\mathrm{SiO}_{2}$ & $\mathrm{Al}_{2} \mathrm{O}_{3}$ & $\mathrm{CaO}$ & $\mathrm{MgO}$ & $\mathrm{Fe}_{2} \mathrm{O}_{3}$ & $\mathrm{Na}_{2} \mathrm{O}$ & $\mathrm{K}_{2} \mathrm{O}$ & $\mathrm{SO}_{3}$ & $\mathrm{P}_{2} \mathrm{O}_{5}$ & $\mathrm{Fineness}\left(\mathrm{m}^{2} / \mathrm{kg}\right)$ \\
\hline PC & 20.5 & 6.50 & 62.5 & 1.90 & 3.20 & - & - & 2.20 & - \\
\hline FA & 11.07 & 9.03 & 22.7 & 1.73 & 27.4 & 0.82 & 1.77 & 6.91 \\
\hline
\end{tabular}

PC: Portland cement; FA: Food processing sludge-derived fuel incinerated ash

Table 1: Composition of raw materials.

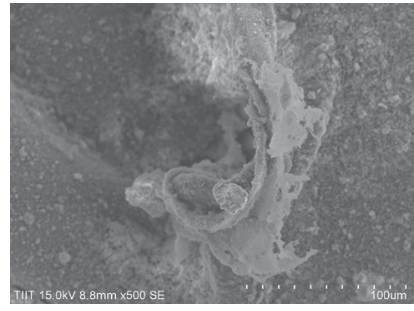

(1) $\times 500$

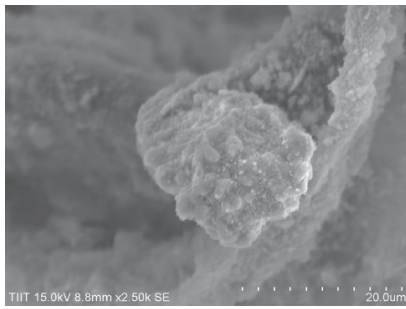

(2) $\times 2500$

Figure 2: SEM microphotograph of food processing sludge-derived fue incinerated ash.

\begin{tabular}{|l|l|l|l|l|}
\hline Properties & PC100FA0 & PC90FA10 & PC80FA20 & PC70FA30 \\
\hline Flow ability (\%) & 103 & 104 & 104 & 104 \\
\hline Water to cement ratio & 0.36 & 0.38 & 0.40 & 0.44 \\
\hline Initial setting (min) & 293 & 471 & 580 & 705 \\
\hline Final setting (min) & 330 & 620 & 661 & 775 \\
\hline
\end{tabular}

PC: Portland cement; FA: Food processing sludge-derived fuel incinerated ash Table 2: Properties of fresh cement paste.

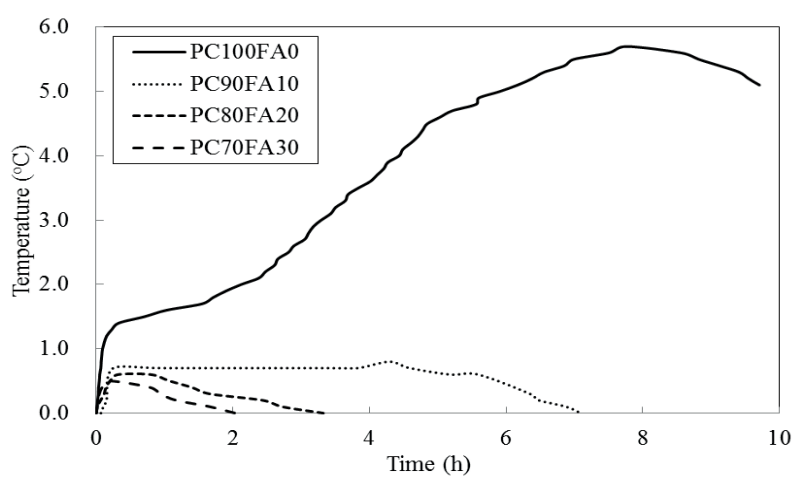

Figure 3: Heat of hydration of fresh cement paste.

\section{Application on soil improvement}

Seed germination: According to the standard germination test specified by ISTA, the Chinese cabbage and water spinach were planted in the original soil and improved soil respectively, observed on a daily basis for 30 days. The seed germination of Chinese cabbage in the original soil on Day 1, Day 3, Day 5, Day 10 and Day 15 was $0 \%, 47 \%, 75 \%, 92 \%$ and $98 \%$ respectively, and that in the improved soil was $0 \%, 81 \%, 93 \%$, $98 \%$ and $98 \%$ respectively. This suggested that the seed germination of Chinese cabbage planted in the original soil and improved soil reached its maximum on Day 14 and Day 7 respectively (98\%)(Figures 7 and 8). In terms of water spinach, the seed germination in the original soil on

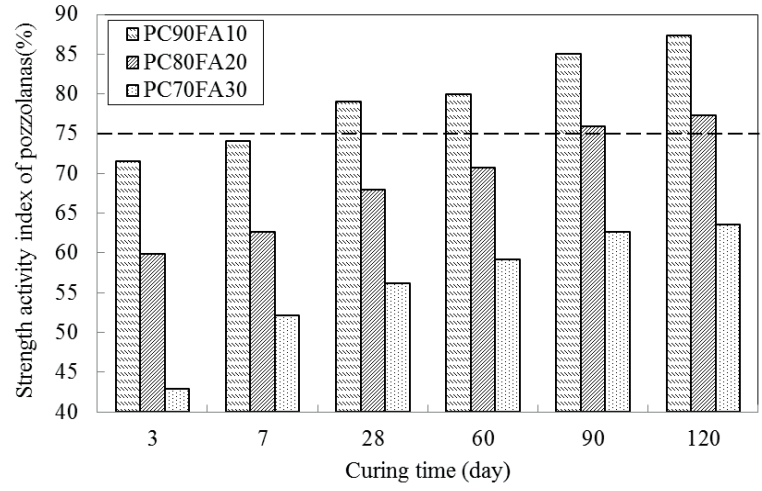

Figure 4: Strength activity index of harden cement paste.

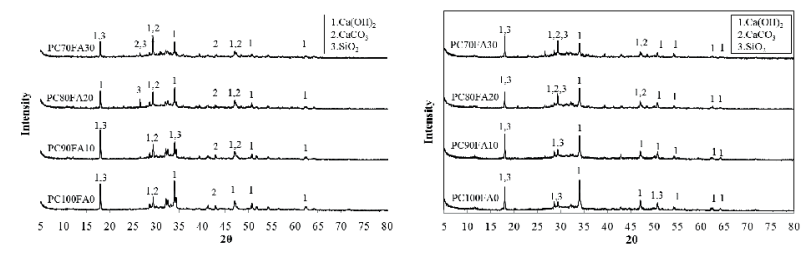

Figure 5: XRD patterns of harden cement paste.
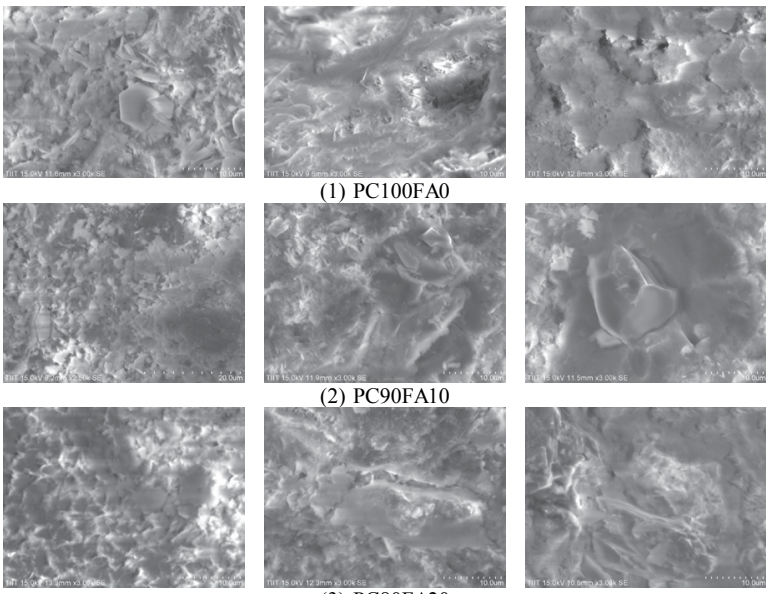

(2) PC90FA10
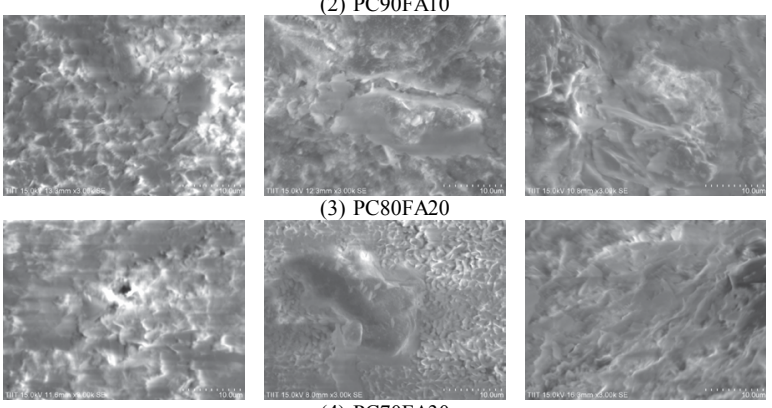

(4) PC70FA30

60-day

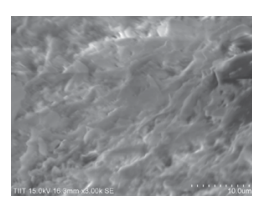

120-day

Figure 6: SEM microphotograph of harden cement paste. 
Citation: Chiou IJ, Su JP, Chen CH, Wu IT (2015) Reuse Resource of Food Processing Sludge-Derived Fuel Incinerated Ash. Int J Waste Resour 5: 187. doi: 10.4172/22525211.1000187

Day 1, Day 3, Day 5, Day 10 and Day 15 was $0 \%, 6 \%, 32 \%, 83 \%$ and $90 \%$ respectively, and that in the improved soil was $0 \%, 5 \%, 35 \%, 75 \%$ and $90 \%$ respectively, suggesting that the seed germination of water spinach planted in the original soil and improved soil reached its maximum on Day 13 (90\%)(Figures 7 and 9). The addition of FA could increase the seed germination of Chinese cabbage in the early stage (3 5 days), but it had no significant effect on water spinach.

\section{Growth rate of vegetables}

The growth rate of the Chinese cabbage planted in the original soil and improved soil increased gradually on Day 2, and reached its maximum on Day 5. It then decreased gradually, and later increased slightly after 15 days (Figure 10a). The water spinach planted in the original soil and improved soil grew significantly on Day 3. The maximum growth rate was reached in the original soil on Day 4 , then decreased gradually, and increased slightly on Day 20 (Figure 10b). The growth rate reached its maximum in the improved soil on Day 7 , then decreased gradually, and increased slightly on Day 20. Overall, the addition of FA had no significant effect on the growth rate of Chinese cabbage and water spinach.

\section{Conclusions}

(1)The FA is in irregular particle shape, so it has high water absorption and low activity. Its water soluble chloride ion content is as high as $0.071 \%$, so it is inapplicable to reinforced concrete.

(2)The addition of FA reduced the hydration heat of fresh FACP greatly by 85.96 91.23\%. Each addition of 10\% FA prolonged the initial setting time and final setting time of fresh FACP by about $49.89 \%$ and $53.84 \%$ respectively.
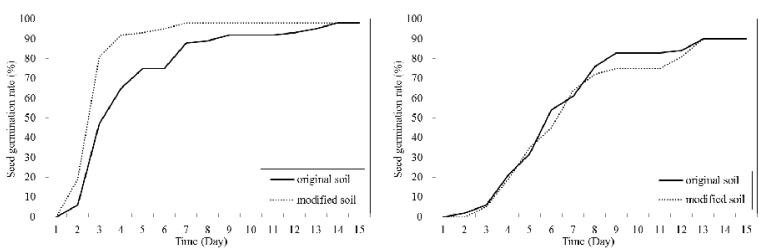

Figure 7: Germination rate of Chinese cabbage and Water spinach.

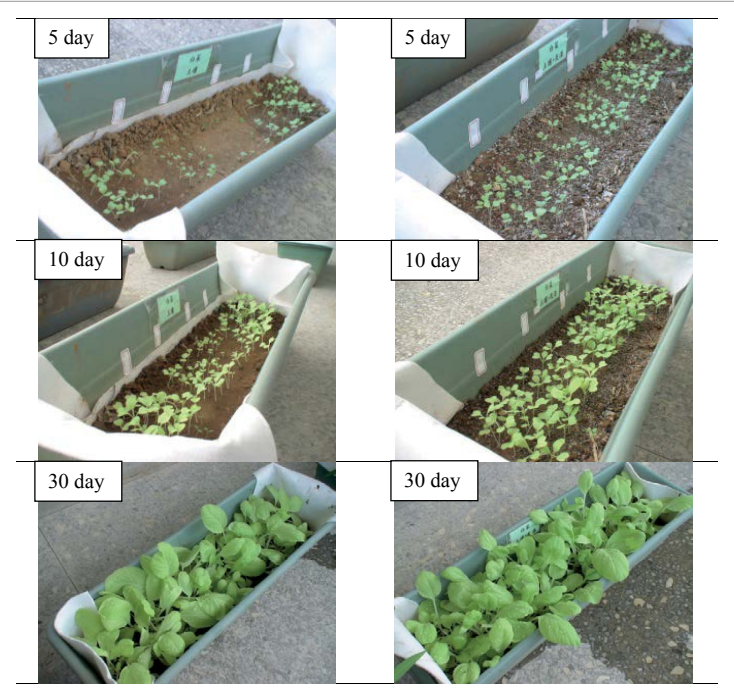

Figure 8: Growth process of Chinese cabbage.

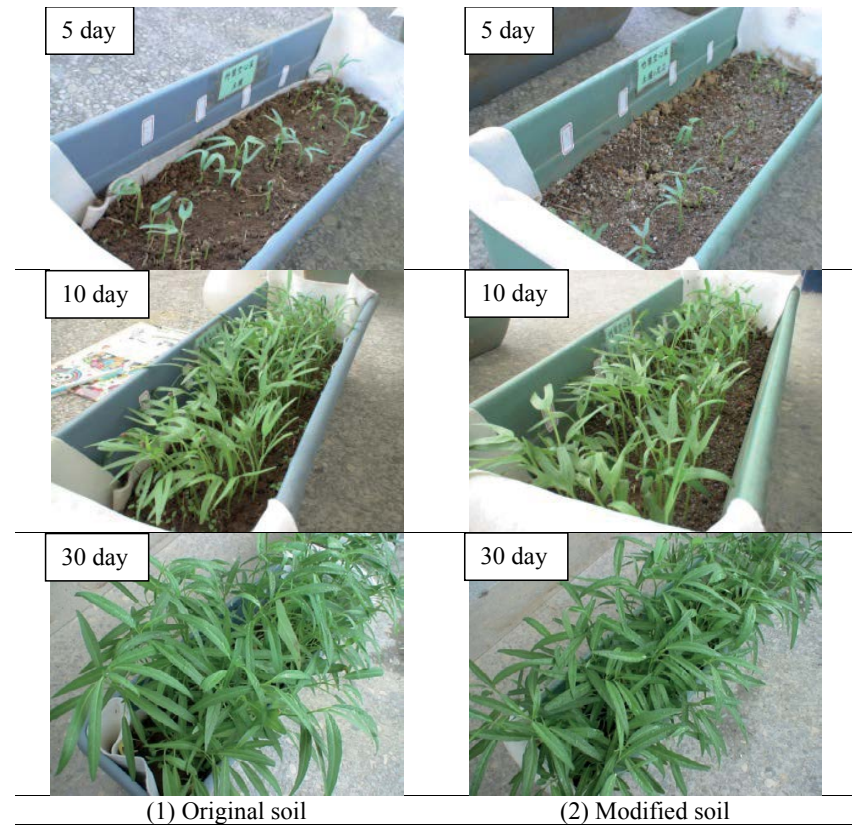

Figure 9: Growth process of Water spinach.
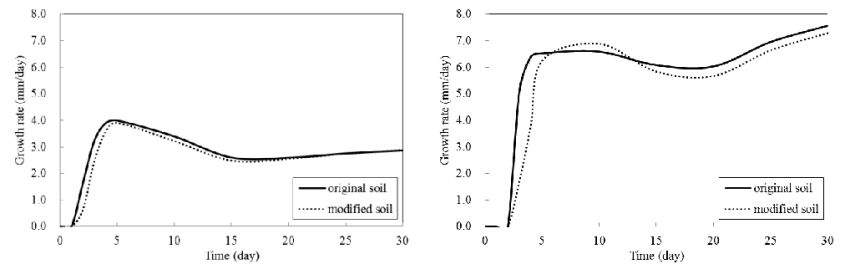

Figure 10: Growth rate of Chinese cabbage and Water spinach.

(3)When the addition level of FA was $10 \%$ and $20 \%$ respectively, the hardened FACP should be cured for 28 days and 90 days respectively, so that the SAI could be greater than $75 \%$. Therefore, the addition level of FA was recommended as $10 \%$.

(4)The final seed germination of Chinese cabbage and water spinach in the original soil and improved soil was $98 \%$ and $90 \%$ respectively. The addition of FA could increase the seed germination of Chinese cabbage in the early stage ( $3 \sim 5$ days), but it had no significant effect on water spinach. The original soil and improved soil had no significant effect on the growth rate of Chinese cabbage and water spinach.

\section{Acknowledgment}

The authors would like to thank the Ministry of Science and Technology (MOST) of the Republic of China, Taiwan, for financially supporting this research under Contract No. MOST102-2221-E-253-002.

\section{References}

1. Lumley SJ, Gollop SR, Moir KG, Tayor WFH (1996) Degrees of reaction of the slag in some blends with portland cements. Cem Concr Res 26: 139-151.

2. Frias M, Sanchez de Rojas IM, Santamaria J, Rodriguez C (2006) Recycling of silicomanganese slag as pozzolanic material in Portland cements: Basic and engineering properties, Cem Concr Res 36: 487-491.

3. Garcia R, Vigil de la Villa R, Vegas I, Frias M, Sanchez de Rojas IM (2008) The pozzolanic properties of paper sludge waste. Constr Build Mater 22: 1484 1490.

4. Chusilp N, Jaturapitakkul C, Kiattikomol K (2009) Utilization of bagasse ash as 
Citation: Chiou IJ, Su JP, Chen CH, Wu IT (2015) Reuse Resource of Food Processing Sludge-Derived Fuel Incinerated Ash. Int J Waste Resour 5: 187. doi: 10.4172/22525211.1000187

Page 5 of 5

a pozzolanic material in concrete. Constr Build Mater 23: 3352-3358.

5. Kroehong W, Sinsiri T, Jaturapitakku C (2011) Effect of Palm Oil Fuel Ash Fineness on Packing Effect and Pozzolanic Reaction of Blended Cement Paste. Procedia Engineering 14: 361-369.

6. Sata V, Tangpagasit J, Jaturapitakkul C, Chindaprasirt P (2012) Effect of W/B ratios on pozzolanic reaction of biomass ashes in Portland cement matrix. Cement Concrete Comp 34: 94-100.

7. Lee G, Ling CT, Wong LY, Poon SC (2011) Effects of crushed glass cullet sizes casting methods and pozzolanic materials on ASR of concrete blocks. Constr Build Mater 25: 2611-2618.

8. Pereira-de-Oliveira LA, Castro-Gomes JP, Santos PMS (2012) The potentia pozzolanic activity of glass and red-clay ceramic waste as cement mortars components. Constr Build Mater 31: 197-203.

9. Al-Sibahy A, Edwards R (2012) Thermal behavior of novel lightweight concrete at ambient and elevated temperatures: Experimental, modelling and parametric studies. Constr Build Mater 31: 174-187.

10. Zhou S, Zhang X, Chen X (2012) Pozzolanic activity of feedlot biomass (cattle manure) ash, Constr Build Mater 28: 493-498.

11. Lee TC, Liu FJ (2009) Recovery of hazardous semiconductor-industry sludge as a useful resource. J Hazard Mater 165: 359-365.
12. Lin KL, Huang WJ, Shie JL, Lee TC, Wang KS, et al. (2009) The utilization of thin film transistor liquid crystal display waste glass as a pozzolanic material. $J$ Hazard Mater 163: 916-921.

13. Terro MJ (2006) Properties of concrete made with recycled crushed glass at elevated temperatures. Build Environ 41: 633-639.

14. Tay JH, Hong SY, Show KY (2000) Reuse Of Industrial Sludge As Pelletized Aggregate For Concrete. J Environ Manage 126: 279-287.

15. Aursen KL, White TJ, Cresswell DJF, Wainwright PJ, Barton JR (2006) Recycling of an industrial sludge and marine clay as light-weight aggregates. $J$ Environ Manage 80: 208-213.

16. González-Corrochano B, Alonso-Azcárate J, Rodas M (2009) Characterization of Lightweight Aggregates Manufactured from Washing Aggregate Sludge and Fly Ash, Resour Conserv Recy 53: 571-581.

17. Ismail ZZ, Al-Hashmi EA (2009) Recycling of waste glass as a partial replacement for fine aggregate in concrete. Waste Manag 29: 655-659.

18. Maier PL, Durham SA (2012) Beneficial use of recycled materials in concrete mixtures. Constr Build Mater 29: 428-437.

19. Chiou IJ, Chen CH (2013) Reuse of Incinerated Ash from Industrial Sludgederived Fuel. Constr Build Mater 49: 233-239.

20. Chiou IJ, Wu IT2 (2014) Evaluating the manufacturability and combustion behaviors of sludge-derived fuel briquettes. Waste Manag 34: 1847-1852. 